\title{
DIE VERHOUDING TUSSEN INTEGRASIE- TEORIE EN KONFLIKTEORIE
}

\begin{abstract}
A.D. Louw
$R G \mathcal{N} *$ Pretoria

ABSTRACT

The author bases his arlicle on a comparison and evaluation of the contributions of conflict theoreticians and consensus theoreticians in dealing with the phenomenon of social conflict. He looks in some detail at the development of conflict theory, and analysis the views of especially Parsons in this regard. The author is of the opinion, however, that pure conflict theory in sociology, in so far as it manifests itself as an alternative orientation with regard to siructural functionalism, should be rejected. He posits the view that there is nothing within the conceptual apparalus of conflict theory which clashes with integration theory, and he accepts the view of Dahrendorf who sees integration theory and conflict theory as applicable in certain situations and their particular demands. He feels that the opposition between the integration model and the conflict model is unfounded.
\end{abstract}

Literatuur oor moderne samelewingsverskynsels het sedert die middelsestigerjare, ná die wydverspreide onrus in veral $\Lambda$ merikaanse stede, toenemend blyke gegee van 'n groeicnde belangstelling in veral die verskynsel van sosiale konflik. Die studente van laasgenoemde onderskei hulself gewoonlik van die integrasie- of konsensusteoretici in diè opsig dat hulle die hedendaagse samelewing vanuit 'n ander hoek wil bestudeer. Vir hulle - die konflikteoretici - is die moderne tegnologiese samelewing meer toepaslik beskryfbaar in terme van mense se botsende belange, en dít wat daaruit voortvloei, as in terme van handeling wat gekenmcrk word deur onderlinge eensgesindheid, samewerking en gekoördineerde organisasie.

Die behoefte aan ' $n$ teorie vir beter begrip van konflik as sosiale verskynsel het veral onder sosioloë se aandag gekom ná die verskyning sowat drie dekades gelede van Jessie Barnard se artikel "Where is the modern sociology of conflict?" (1950). Hierna het daar'n polemick ontstaan tussen konsensusen konllikteoretici wat gekenmerk is deur reaksionêre kommentaar op, in besonder, die geskrifte van Talcott Parsons. Die debat is geïnisieer en in stand gehou vanuit hoofsaaklik die kamp van die konflikteoretici.

- Die standpunte vervat in lierdie artikel weerspieél nie noodwendig dié van die RGN nie

48(4) 1983 


\section{Die verhouding tussen}

Die moderne konflikteorie kan in die woorde van Kinloch kortliks saamgevat word as verteenwoordigend van "a systemic, evolutionary and radical reaction to contemporary forms of conflict and domination theories developed by European-oriented intellectuals within the context of a conflict-ridden and exploit ive culture" (1977:246). 'n Nuttige en algemene definisie van konflik vind ons by Coser wat dit formuleer as "a struggle over values and claims to scarce status, power and resources in which the aims of the opponents are to neutralize, injure or eliminate their rivals" (1956:8).

In terugblik op die bydrae van Parsons is dit die mening van die skrywer dat sekere aspekte van Parsons se beskouinge dikwels negeer of onderbeklemtoon word ten einde polemiekonthalwe 'n sterk opponerende standpunt in te neem, maar dat 'n juiste vertolking van Parsons eerder dui op 'n fundamentele verenighaarheid tussen die struktuurfunksionalisme en konflikteorie.

Parsons het vele kritici gehad ten opsigte van sy opvattinge oor sosiale verandering, konflik, ekwilibrium en integrasie - in besonder vanaf die kant van die konflikteoretici. (Vgl. o.a. Gouldner, 1970; Dahrendorf, 1968; Lockwood, 1950; Mills, 1959 en Moore, 1966.) Betreffende laasgenoemde is die volgende opmerkinge egter toepaslik: konflikteorie is self blootgestel aan verskeie kritiese oorweginge soos, eerstens, dat dit die feit dat die verskynsel van maatskaplike stabiliteit 'n gegewene is negeer, asook die feit misken dat stabiliteit eerder as onstabiliteit 'n kenmerk van die meeste samelewings is. Tweedens, konflik, geïnterpreteer op samelewingsvlak, vind altyd plaas binne, of tussen, spesifieke bestaande strukture waarvan 'n sekere mate van kennis onontbeerlik is vir begrip van onder andere die oorsake, ontplooiing en uitvloeisels van konflik. Derdens, konflik behels minstens ' $n$ mate van 'konsensus' tussen groepe aangaande die kwessie waaróm die konflik gaan sowel as 'n sekere mate van 'konsensus' binne groepsgeledere na aanleiding waarvan polarisering ten opsigte van 'n ander groep (of groepe) moontlik word. 'n Eensydige konflikperspektief moet dus noodsaaklikerwys die bestaan van 'n sekere vlak van orde, kontinuïteit van strukture en aanwesigheid van 'n minimum van konsensus reeds voorveronderstel alvorens enige aspek van konflikstudie sinvol onderneem kan word. Dit betcken dat ' $n$ konflikbenadering hoogstens komplementêr kan funksioneer in stede van sigself as alternatief vir die funksionele benadering aan te bied.

Die ontstaan van konflikteorie moet gesien word as 'n reaksie op hoofsaaklik 'n aanvanklike leemte in die ontwikkelingsverloop van struktuurfunksionele teorie - 'n leemte wat veral aangevoel is deur sosioloë wat na verklarings vir 
konflikverskynsels in die moderne geïndustrialiseerde samelewings gesoek het.

Die ontstaan van hierdie leemte is egter heel begryplik in die lig van wat in die struktuurfunksionalisme as doelstelling voorgehou is. In sy The Structure of Social Action (1968) ont wikkel Parsons'n gesintet iseerde konseptuele skema met die doel om 'n meer toereikende grondslag dáár te stel vir die identifisering van tipes sosiale verskynsels asook om ' $n$ besondere analitiese strategie vir voortgesette sosiologiese teoriebou tot stand te bring. In hicrdie werk onderneem Parsons om 'n reeks fundamentele konsepte byeen te bring "(that) adequately 'grasp' aspects of the objective external world ... These concepts correspond not to concrete phenomena, but to elements in them which are analytically separable from other elements" (p. 730). Hierdie fundamentele analitiese en hoogs abstrakte konsepte dien weer as rigsnoer en grondslag vir die ontwikkeling van 'n "generalized system of concepts" wat op geintegreerde wyse breë empiriese heenwysing het.

Parsons het hiermee beoog om uiteindelik analitiese konsepsisteme te skep aan die hand waarvan die maatskaplike realiteit ten opsigte van sy uiteenlopende tipes sosiale verskynsels sistemies en sistematies bestudeer en begryp kan word. Die klem was vir hom op onderling-samehangende analitiese subsisteme van konsepte in ooreenstemming met sistemiese aspekte van die maatskaplike realiteit en nié op die ontwikkeling van subsisteme van proposisies nie (pp. 6-15). Slegs wanneer hierdie subsisteme van konsepte toereikend saamgestel was, kon operasionele definisies ont werp word vir terugvoering in die subsisteem en konsepte aangewend en geînkorporeer word in algemene teoretiese stellings aangaande die verskillende aspekte van die maatskaplike realiteit. Hierdie strategie vir teoriebou is deurgaans deurgevoer en toegepas in Parsons se latere werke tot by sy oorlyde in 1979.

Dit is duidelik uit Parsons se geskrifte dat sy aandag toegespits was op die feit dat sosiale strukture kontinuïteit vertoon en dat die samelewing as geheel, ten spyte van stremminge binne of tussen spesifieke subsisteme, tog ' $\mathrm{n}$ groot mate van ewewigtigheid bly handhaaf. Dit was hierdie eienskap van volgehoue en oorheersende ekwilibrium wat aanleiding gegee het tot die ont wikkeling van 'n orde-gerigte tcoretiese oriëntasie in die struktuurfunksionalisme en is dit begryplik dat verskynsels van 'afwyking' en 'niekonformering' oorwegend vanuit hierdie perspektief beskryf en verklaar sou word. 


\section{Die verhouding tussen}

Gepaardgaande hiermee is dit nodig om daarop te let dat Parsons se begrippe teoretiese konstruksies is wat op die algemeenheid van verskynsels betrekking het en nie voorgee om presiese weergawes van elemente in die empiriese werklikheid, soos ons dit in die daaglikse omgang ervaar, te wees nie. Geen wonder dus dat hy vanuit sy analitiese sisteem die ekwilibriumversteurende verskynsels relatıef beskryf soos weerspieël in terme soos "strain", "disturbance", "tension" en "coping mechanisms" nie.

Parsons erken ook in sy teorie oor sosiale verandering dat stremminge in die interaksiesisteem tot spanning en vyandigheid kan lei. Terselidertyd beskou hy hierdie teorie nog as 'n "partial explanation in terms of certain elements" en gee toe dat "we do not in present state of knowledge possess a general theory of the processes of change in societies as a whole" (1951:534). Sy teorie oor sosiale verandering was dus een van voorlopigheid, maar hy stel dit as 'n eis dat 'n toereikende teorie "equally applicable to the problems of change and to those of process within a stabilized system" (p. 535) moet wees, en verwerp om hierdie rede die teenstelling van statiese en dinamiese teorieë van verandering. Dit is teen die agtergrond van sy latere werke oor ewolusionêre ontwikkeling dat die noodsaaklikheid en belangrikheid van 'n verklaring vir die kontinuïteit van sosiale strukture veral duidelik word (1966:1971). Tereg merk Johnson op dat Parsons maatskaplike ordelikheid as 'n probleem benader het wat verklaar moes word en nie as 'n vanselfsprekendheid aanvaar moet word nie (1975:35).

Lockwood het in 1950 aangevoer dat die a anvaarding van die samelewing as 'n sisteem van ekwilibrium daartoe lei dat die daaropvolgende analises daarvan onvermydelik daardie meganismes beklemtoon wat maatskaplike orde in die hand werk eerder as diè wat stelselmatig wanorde en verandering meebring. Sy beswaar is onder meer die volgende: die Parsoniese konseptuele skema "is highly selective in its focus on the role of the normative order in the stabilisation of social systems" (p. 140).

So 'n fokus op normatiewe orde behoort egter op sigself geen belemmering mee te bring by die bestudering van konllik nie as in gedagte gehou word dat laasgenoemde ook die normatiewe definisics van die situasie behels. Belangrik is egter Parsons se doelstelling met sy teoretiese poging, naamlik om vanuit ' $n$ spesifieke perspektief' $n$ omvattende en geïntegreerde raamwerk vir 'n breë begrip van die maatskaplike realiteit te ontwikkel voordal die besonderhede van elke faset van hierdie realiteit uitgewerk word.

Parsons is nie onbewus van die alomteenwoordigheid van 'n sekere mate van 
dissensie waar konsensus ook al aangetref word nie. Hy merk onder andere op dat "no complex collective system can operate unless there is a relative concentration of authority and power by virtue of which many decisions binding on the collectivity as a whole are taken without the full consent of all participant members" (1978:53). Dieselfde gedagte word weerspieël in die volgende stelling: "In principle, propositions about the factors making for the maintenance of the system are at the same time propositions about those making for change" (1951:231). Dit is dus onbillik om integrasieteorie sonder meer as ontoereikend vir die hantering van konflik of vir die voortbring, of akkommodasie, van konflikteorie te bestempel. Merton het reeds as funksionalis in hierdie rigting 'n bydrae gelewer met sy "theory of reference groups" (1957:Hfst. 8) en sy onderskeiding tussen afwykende en nie-konformerende gedrag (pp. 357-368) - laasgenoemde wat hy met sosiale verandering in verband bring - terwyl die werk van Coser (1956) en Himes (1966) toon dat konflik doeltreflend vanuit 'n konflikfunksionele standpunt bestudeer kan word. 'n Noemenswaardige studie waarin gedemonstreer word hoe die ontstaansbronne van sowel integrasie as konflik gelyktydig binne gemeenskapsverband ondersoek kan word is deur Coleman (1976) aangetoon.

Die suiwer konflikperspektief in die sosiologie in soverre dit sigself as 'n alternatiewe oriëntasie teenoor die struktuurfunksionalisme stel, behoort myns insiens afgewys te word. ' $n$ Voorbeeld van so 'n ekstreme standpunt in die geledere van die konflikteoretici vind ' $n$ mens in 'n uitspraak soos die volgende: "I believe that the only viable path to a comprehensive explanatory sociology is a conflict perspective, in which solidarity of any particular sort is just one outcome among many to be explained ..." (Collins, 1975:21). Die skrywer daarvan wys die begrip "sisteem" af as 'n mite en beskou "needs of the system" as "a way of expressing preferences for what a theorist believes is good, not a causal explanation of the way things actually happen" (ibid.). Collins het dit hier teen die integrasieteorie se beperkte hantering van konflik tot op datum. Sy kritiek is juis gerig op daardie faset van die integrasieteorie wat nog nie tot ontplooiing gebring is nie en dus nog 'n lcemte laat.

Tog is daar niks in die konseptuele apparaat van konflikteorie wat teenstrydig is met dié van integrasietcorie nie en beskik konflikteorie ook oor geen plaasvervangende teoretiese beeld nie. Volgens Duke bestaan daar genocg gedetailleerde studies op empiriese vlak om pogings tot kodifiëring en sintetiscring te reguerdig, maar "these data have not been incorporated into a comprehensive theory of social conflict. The gap between theory and 


\section{Die verhouding tussen}

fact is still gaping and little has yet been done to close it. So-called 'conflict theory' exists as broad postulates or domain assumptions about the nature of social life, together with a wealth of illustrative material to support these assumptions. It is 'pre-theoretical' rather than 'theorctical' ..." (1976:202). Konflikteorie het dus inderdaad geleentheid om 'n substansiële bydrae te lewer ter vulling van 'n leemte waarin die gangbare globale teorie agterweë gebly het. As fundamentele strategie het dit egter enersyds geen verklaring vir die bestaan, oorsprong of kontinuiteit van sosiale strukture nie; andersyds voorveronderstel dit tog noodsaaklikerwys die bestaan daarvan as voorwaarde vir elke empiriese studie. Daarby het dit 'n te groot agterstand op die gebied van sistematicse teorie om enigsins as plaasvervanger vir die struktuurfunksionalisme te kan instaan.

Ek meen voorts dat, in ag genome die huidige stand van konflikteorie, Dahrendorf steeds gelyk het wanneer hy die integrasieteorie én die konflikteorie as aanwendbaar sien in terme van situasievereistes. "As far as I can see, we need both models for the explanation of sociological problems ... Strictly speaking, it does not matter whether we select for investigation problems that can be understood only in terms of the equilibrium model or problems for which the conflict model is required. There is no instrinsic criterion for preferring one to the other" (1968:128). Die keuse van 'n model hang dus af van die navorser se eie doelstelling. Dahrendorf merk elders op dat "in the conceptual arena of sociological analysis they exist side by side" (1959:163). Hierteen maak Zeitlin beswaar aangesien dit wéér dui op twee teorieë "lying 'side by side', as if these correspond to the actual elements of a bifurcated reality" (1973:1 18). Teen so 'n tipe beswaar het ook Dahrendorf nie 'n oplossing nie. "I have to reserve judgement ... unification of theory is not feasible at a point which has puzzled thinkers ever since the beginning of Western philosophy"' (1959:164).

Sonder om my aan 'n kitsoplossing vir hierdie probleem te waag meen ek dat die volgende opmerkings tog toepaslik mag wees: die integrasiemodel leen sig uiteraard tot die verheldering van wydstrekkende en omvattende teoretiese oorwegings terwyl die konflikmodel meer pertinent gerig is op die plek en onderlinge verband van en tussen spesifieke konflikveranderlikes soos mobilisering, omvang, eskalasie, intensiteit en regulering. Dit gaan dus hier wesentlik om verskillende vlakke van abstraksie en kan konflikteorie gesien word as behorende tot, of bewegende na, sogenaamde "middle-range theory". Juis aangesien die twee modelle op verskillende vlakke van abstraksie heenwys - en beide nog onvolledig is - is daar nie op hierdie stadium ' $n$ integrasie van teoretiese benaderings moontlik nie sodat enige 
pogings daartoe, soos dié van Pierre van den Berghe (1963), as enigsins tentatief of prematuur beskou moct word niet eenstaande die voortreflikheid daarvan.

Dit wil dan voorkom of die teenstelling tussen integrasiemodel en konflikmodel ongegrond is. Eerstens, die modelle beantwoord andersoortige vrae en vind hul aanwending op verskillende vlakke van ondersoek. Tweedens, die één impliseer in mindere of meerdere mate juis die bestaan van die ander weens die onvolledigheid van albei. (Die struktuurfunksionalistiese model gaan immers self nog gebuk onder 'n leemte soos vroeër vermeld.)

Konflik is 'n maatskaplike proses wat binne of tussen sosiale strukture plaasvind. Logies vere is 'n sistematiese studie van die samelewing dus eers 'n kennis van die strukture self waarbinne of waartussen konflik bestudeer word. ' $n$ Konflikmodel is dus afhanklik, in mindere of meerdere mate, van 'n meer omvattende strukturele model in 'n nie-omkeerbare verhouding wat aan eersgenoemde by uitstek 'n komplementêre karakter verleen, en dit wat komplementêr is kan nie as onafhanklike alternatief gestel word teenoor'n model wat dit logies voorafgaan nie. Om hierdie rede is konflikteorie aanvaarbaar terwyl die konflikperspektief as onafhanklike standpunt afwysbaar is.

'n Verdere verhelderende en breëre visie op die plek wat konflikteorie kan inneem in sosiologiese teorie mag verkry word by 'n nadere blik op Dahrendorf se stipulering van vier fundamentele aannames vir wat hy noem die dwangteorie van 'n samelewing. Hy poneer die volgende:

1. Every society is at every point subject to processes of changc; social change is ubiquitous;

2. Every society displayes at every point dissensus and conflict; social conflict is ubiquitous;

3. Every element in a society renders a contribution to its disintegration and change;

4. Every society is based on the coercion of some of its members by others" (1959:162).

Die eerste stelling kan net so aanvaar word met die klem op 'subject to'. Die tweede stelling is een van ekstremiteit. In die teendeel kan beweer word dat geen samelewing dissensie en/of konflik vertoon op clke punt nie. In soverre dit dui op die moontlikheid dat 'n samelewing op enige punt dissensie of konflik kan vertoon, sê die stelling niks meer as wat reeds in die eerste stelling 


\section{Die verhouding tussen}

vervat is nie. Wat die derde stelling betref is dit ook één van ekstremiteit en geld slegs die moontlikheid daarvan op enige punt. Stelling vier is, net soos die eerste een, vanselfsprekend in moderne samelewings. Indien die ekstreme elemente uit die tweede en derde stellings - verteenwoordigend van die konflikperspektief - verwyder word, is daar niks in hierdie aanvaardinge wat nie verenigbaar is met 'n verder uitgewerkte integrasieteorie nie.

Dit wil dan voorkom of met die afwysing van die konflikperspektief daar grondliggende verenigbaarheid moont lik is tussen die struktuurfunksionalisme en konflikteorie, en dat deur die verkeerdelike gelykstelling van laasgenoemde met die konflikperspektief die teenoorstelling van integrasieteorie en konflikteorie ongegrond en foutief is.

\section{BRONNELYS}

BERNARD, JESSIE. 1950. "Where is the modern sociology of conflict?" American .Journal of Sociology, 56, pp. 11-16.

COLEMAN, J.S. 1976. Community disorganisation and conflict. (In: MERTON, R., NISBET, R. (eds) Contemporary social problems, 4th ed. New York, Harcourt.)

COLLINS, R. 1975. Conflict sociology: towards an explanatory science. New York, Academic Press.

COSER, L.A. 1956. The functions of social conflict. London, Routledge and Kegan Paul.

DAHRENDORF, R. 1959. Class and class conflict in industrial society. Standford, Stanford University Press.

DAHRENDORF, R. 1968. Essays in the theory of society. London, Routledge and Kegan Paul.

DUKE, J.T. 1976, Conflict and power in social life. Provo, Utah, Brigham Young University Press.

GOULDNER, A. 1970. The coming crisis of western sociology. New York, Basic Books.

JOHNSON, B. 1975. Functionalism in modern sociology: understanding Talcott Parsons. Morristown, N.J., General Learning Press.

KINLOCH, G.C. 1977. Sociological theory. New York, McGraw-Hill.

LOCKWOOD, D. 1950. "Some remarks on 'The social system'." British .Journal of Sociology, 7, pp. 134-146.

MERTON, R.K. 1957. Social theory and social structure. Chicago, Free Press. MILLS, C. Wright. 1959. The sociological imagination. New York, Oxford 
University Press, pp. 44-49.

MOORE, B. Jr. 1966. Social origins of dictatorship and democracy. Boston, Beacon Press, p. 486.

PARSONS, Talcott. 1951. The social system. New York, Free Press. PARSONS, Talcott, SHILIS, Edward A. (eds) 1951. Toward a general theory of action. Cambridge, Massachusetts, Harvard University Press.

PARSONS, Talcott. 1966. Societies: Evolutionary and comparative perspectives. Foundations of Modern Sociology Series, Englewood Cliffs, I.J. Prentice Hall.

PARSONS, Talcott. 1968. The structure of social action. New York, Free Press.

PARSONS, Talcott. 1978. Action theory and the human condition. New York, Free Press.

VAN DEN BERGHE, Pierre. 1963. "Dialectic and functionalism: toward reconciliation." American Sociological Review, 28 (5), pp. 695-705.

ZEITLIN, I.M. 1973. Rethinking sociology. Engelwood Cliffs, N.J., Prentice Hall. 